\title{
Analysis of Sino-Russia-Magnolia Trade Cooperation Potential: Based on the Perspective of Trade Gravity Model \\ Qian Shen
}

Faculty of Economics, Inner Mongolia University of Finance and Economics, Hohhot 010030, China

Keywords: Sino-Russia-Magnolia,Trade Gravity Model,Trade Potential

\begin{abstract}
This paper sets the three bilateral trade flows (1999-2014) as the basis of analysis and adds trade system arrangement policy variable within the classical trade gravity model. It also constructs the panel data model of three bilateral trade between China,Russia and Mongolia. The empirical results show that (1) China and Russia bilateral trade increase apparently; China and Mongolia have a coordinated growth of bilateral trade; Russia and Mongolia maintain an uneven development of bilateral trade. (2) The three bilateral trade flows are largely driven by economies of scale, the relative distance and trade relationship. (3) Sino-Russia and Sino-Mongolia's bilateral trade belong to trade potential pioneering type and there is still a transaction gap which should be dug deeply. Russia-Mongolia's trade is close to the huge potential type, especially the Mongolia exports to Russia.
\end{abstract}

\section{Introduction}

On July 9, 2015, President, XI Jinping held meeting with Russia President Vladimir Putin and Mongolian President Elbegdorj in Ufa. <A Road Map of Tripartite Cooperation in the Medium-Term > approved by the three heads proposed to strengthen the tripartite trade, investment and business partnerships. This work tries to describe the bilateral trade situation, the driving factors and the trade potentialities in the future.

\section{Analysis of Sino-Russia-Magnolia Bilateral Trade Situation}

From Figure 1, the Sino-Russia bilateral trade volume had an increase of 21 times, leading a growth trend. Russia's exports to China is mainly original, timber and other resources intensive products. China's exports to Russia's is primarily electrical main textile, light industry, toys and etc. Figure 2 reveals Sino-Mongolia bilateral trade had an increase of 33 times which grew from U.S. \$ 2.13 million to U.S. \$ 72.86 million. Sino-Mongolia trade experienced transitions in 2001 for China to Mongolia's exports declined, but Mongolia to China's export surged. China largely exported to Mongolia manufactured goods and articles for daily use whereas Mongolia generally exported minerals, animal products and textiles to China. Regional trade is in a state of with low value-added and low-end products. From Figure 3, Russia and Mongolia bilateral trade volume is small and Russia is in a dominant position. Mongolia's exports climbed next to 12 times in 15 years, but Mongolia to Russia's export volume has been low. Russia's high tariffs on Mongolian goods and the improvement of Russian railway freight are the bottleneck restricting the development of Russian trade rapidly. 


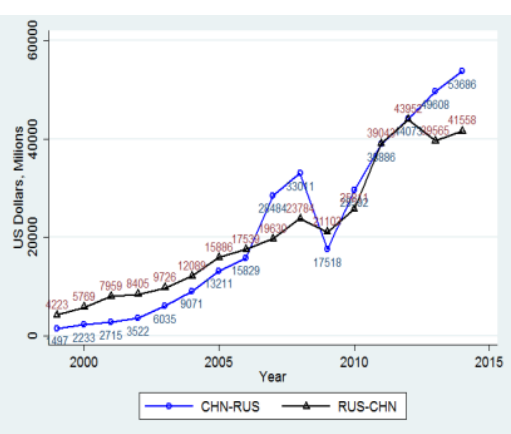

Fig.1. China and Russia Trade Trends (1999-2014)

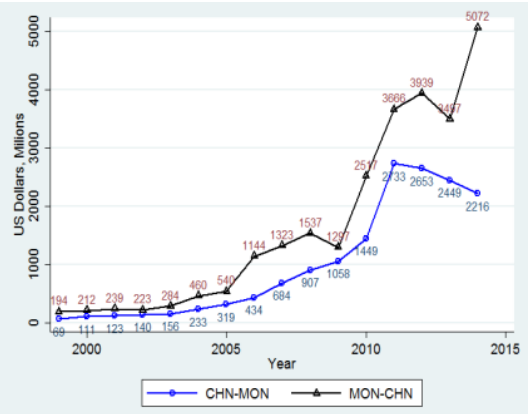

Fig.2. China and Mongolia Trade Trends (1999-2014)

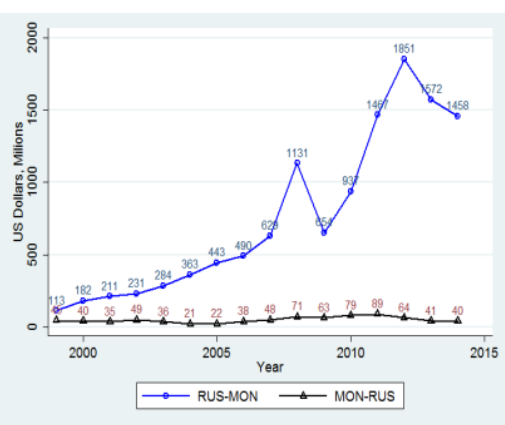

Fig.3. Russia and Mongolia Trade Trends (1999-2014)

\section{Model Specification and Data Source Descriptions}

3.1 Model Specification. Earliest trade gravity model merely considers the economic aggregate and the distance. The consequent research results widened the determinants of bilateral trade. These variables contain population size[1], per capital gross domestic product[2], exchange rate[3]. Whether to belong to an economic organization[4] as well as the different meanings of virtual variables are introduced into the analysis. This paper uses the trade gravity model general form as follows:

$$
\ln T_{i j t}=\ln A+\beta \ln \left(Y_{i t} Y_{j t}\right)+\gamma \ln D_{i j}+\delta S_{i j t}+\varepsilon_{i j t}
$$

\subsection{Data Source Descriptions}

Table 1. Data Sources and Description

\begin{tabular}{l|l}
\hline \multicolumn{1}{c|}{ Variable (Meaning) } & \multicolumn{1}{c}{ Source } \\
\hline $\mathrm{T}_{\mathrm{ijt}}($ trade flows of country $\mathrm{i}$ export to $\mathrm{j}$ in $\mathrm{t}$ period $)$ & International monetary fund database \\
\hline $\mathrm{Y}_{\mathrm{it}} / \mathrm{Y}_{\mathrm{jt}}($ gross domestic product of country $\mathrm{i}$ and $\mathrm{j}$ in $\mathrm{t}$ period $)$ & world-development-indicators \\
\hline $\mathrm{D}_{\mathrm{ijt}}($ relative distance between country $\mathrm{i}$ and $\mathrm{j})$ & Indonesian Website \\
\hline
\end{tabular}

Data sources: the author sorted.

Table 2. Virtual Variable Description

\begin{tabular}{|c|c|c|}
\hline $\begin{array}{c}\text { Variable } \\
\text { ( Meaning) }\end{array}$ & Important Point & Specific Set \\
\hline \multirow{3}{*}{$\begin{array}{l}\mathrm{S}_{\mathrm{ijt}} \text { (On behalf } \\
\text { of the } \\
\text { institutional } \\
\text { arrangement } \\
\text { in favour of } \\
\text { trade between } \\
\text { the two } \\
\text { countries) }\end{array}$} & $\begin{array}{l}\text { In 2003, China and Russia agreed to strengthen and } \\
\text { develop good-neighborly friendship and strategic } \\
\text { partnership of coordination between the two countries }\end{array}$ & $\begin{array}{l}\text { China and Russia before } 2003 \text { sets to } 0 \text {, } \\
\text { after } 2003 \text { (including 2003) sets to } 1\end{array}$ \\
\hline & $\begin{array}{l}2003 \text { years as the two countries enacted the } \\
\text { good-neighborly partnership of mutual trust, bilateral } \\
\text { relations entered into a new stage of development }\end{array}$ & $\begin{array}{l}\text { China and Mongolia before } 2003 \text { set to } \\
0 \text { (including 2003) after } 3 \text { years to } 1\end{array}$ \\
\hline & $\begin{array}{l}\text { Mongolian President Nambaryn Enkhbayar visited Russia } \\
\text { in 2006, the two sides signed the <Declaration of } \\
\text { Moscow>, Mongolia-Russian relations entered a stage of } \\
\text { full recovery }\end{array}$ & $\begin{array}{l}\text { Mongolia and Russia sets to } 0 \text { before } \\
2006 \text {, the indicator of the two countries } \\
\text { after six years (2006) sets to } 1\end{array}$ \\
\hline
\end{tabular}

Data sources: the author sorted.

\section{Empirical Analysis}

This work has carried on the Hausman test and panel regression analysis by using STATA 14.0 software on sample data.

4.1 Hausman Test. Table 2 shows that all three models declined the Hausman test null hypothesis. The results refuse the original hypothesis. That means a random effects model must be taken into the analysis. 
Table 3. Hausmann Test Results

Test: Ho: difference in coefficients not systematic

\begin{tabular}{l|l}
\hline Sino-Russia Trade Model & Prob $>$ chi2 $=0.3100$ \\
\hline Sino-Mongolia Trade Model & Prob $>$ chi2 $=0.9997$ \\
\hline Russian-Mongolia Trade Model & Prob $>$ chi2 $=0.1899$ \\
\hline
\end{tabular}

Data Sources: calculated by the author.

4.2 Regression Results. This work adopts random effects model. The estimations are shown in table 3.

Table 4. Panel Regression Results of Sino-Russia-Mongolialia Gravity Model of Bilateral Trade

\begin{tabular}{cccc}
\hline & Lnexportij(China-Russia) & Lnexportij(China-Mongolia) & Lnexportij(Russia-Mongolia) \\
\hline lngdp & 0.466 & 0.669 & 0.336 \\
& $(8.56)^{* * *}$ & $(26.32)^{* * *}$ & $(3.27)^{* * *}$ \\
lndistr & 0.2 & 0.087 & -0.454 \\
& $(2.84)^{*}$ & $(10.24)^{* *}$ & $(15.74)^{* * *}$ \\
\multirow{2}{*}{ scij } & 0.336 & 0.129 & 0.43 \\
& $(-1.89)^{* * *}$ & $(-1.35)^{*}$ & -1.27 \\
\multirow{2}{*}{ cons } & -19.283 & -28.214 & -7.928 \\
& $(7.03)^{* * *}$ & $(22.84)^{* * *}$ & $(-1.61)^{*}$ \\
\multirow{2}{*}{$N$} & 32 & 32 & 32 \\
\hline
\end{tabular}

Notes: $* \mathrm{p}<0.1 ; * * \mathrm{p}<0.05 ; * * * \mathrm{p}<0.01, \mathrm{Z}$ value in brackets。

Continuous variable coefficient of the natural logarithm (such as $\mathrm{Y}$ and D ) expresses elastic[7]. But virtual variables (such as $\mathrm{S}_{\mathrm{ijt}}$ ) coefficient need to be interpreted as elastic after conversion: $E=\exp (\delta)-1[8], \quad \delta$ is an estimated coefficient for a virtual variable[9].

Regression results reflect three aspects. Firstly, the three bilateral regression coefficients of GDP is positive significant at $1 \%$ level[10]. Second, the influence of the relative distance passes the test of significance. The coefficient of relative distance between China and Russia reaches 0.2, which demonstrates that the two countries in the world production capacity are reinforced and weak the actual distance factor. Third, in virtual variable inspection, China-Russia trade institutional arrangements' significance level is remarkably high.

4.3 Potential analysis of Bilateral Trade. Gravity model of trade potential is based on estimates of potential trade, then compares the potential value with the actual trade volume[11]. Provided that the actual trade value is greater than the estimate, the condition is called excessive trading subsequently. Trade potential values fall into three categories by 0.8 and 1.2 standards. The first class is a potential type which quantity is greater than or else equal to 1.2. The second category is between 0.8 and 1.2 and the third type is less than 0.8. Figure 4 shows the potential of China-Russia-Mongolia's bilateral trade.

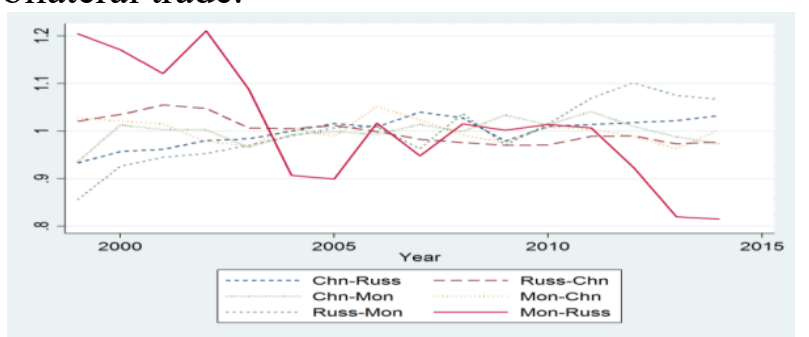

Fig.4. Bilateral Trade Potential between China, Russia and Mongolia

\section{Conclusion}

This paper adds trade system arrangement policy variable within the classical trade gravity model and constructs the panel data model of three bilateral trade between China, Russia and Mongolia. It 
adopts the three bilateral export trade flows as the research object, discussing the influential factors of affecting trade flows and predicts the potential trade meanwhile. Calculation of trade potential shows the strategic arrangement of regional economic integration between Sino-Russia-Mongolia can effectively release the commercial potential.

\section{References}

[1] Sawyer JA, An Econometric Study of International Trade Flows by Hans Linnemann, Canadian Journal of Economics \& Political Science, vol. 20, pp. 92-99, 1967.

[2] Leamer EE, The Commodity Composition of International Trade in Manufactures: An Empirical Analysis, Oxford Economic Papers, vol. 26, pp. 350-74, 1974.

[3] Bergstrand JH, The Gravity Equation in International Trade: Some Microeconomic Foundations and Empirical Evidence.: Some Microeconomic Foundations and Empirical Evidence, Review of Economics \& Statistics, vol. 67, pp. 474-81, 1985.

[4] Bergstrand JH, The Generalized Gravity Equation, Monopolistic Competition, and Factor-Proportions Theory in International Trade, Review of Economics \& Statistics, vol.71, pp. 143-53, 1989.

[6] Matyas L, Proper Econometric Specification of the Gravity Model, World Economy, vol. 20, pp. 363-368, 1997.

[7] Zhang J and Gustav K, A Gravity Model with Variable Coefficients: The EEC Trade with Third Countries, Geographical Analysis, vol. 27, pp. 307-320, 2010.

[8] Tsangarides CG, Mirestean A and Chen H, Limited Information Bayesian Model Averaging for Dynamic Panels with an Application to a Trade Gravity Model, Imf Working Papers, vol. 11, pp. 230, 2011.

[9] Anderson JE and Yotov YV, The Changing Incidence of Geography, American Economic Review, vol.100, pp. 2157-2186, 2008.

[10] Helpman E, Melitz M, Rubinstein Y, Estimating Trade Flows: Trading Partners And Trading Volumes, Quarterly Journal of Economics, vol. 123, pp. 441-487, 2008.

[11] Burger M, van Oort F, Linders G, On the specifiaction of the gravity model of trade: zeros,excess zeros and zero-infalted estimation, Erim Report, vol. 4, pp. 167-190, 2009. 